Павло Вікторович Опенько (канд. техн. наук)

Олексій Ростиславович Мартинюк (канд. техн. наук) ${ }^{1}$

Ігор Миколайович Клюшніков (канд. техн. наук, с.н.с.) $)^{2}$

Олексій Віленинович Никифоров (кано. техн. наук, с.н.с.)

${ }^{1}$ Національний університет оборони Украйни імені Івана Черняховського, Київ, Украӥна
${ }^{2}$ Харківській національний університет Повітряних Сил імені Івана Кожедуба, Харків, Украйна

\title{
МЕТОДИКА ОБґРУНТУВАННЯ РАЦІОНАЛЬНОГО СКЛАДУ ПЕРСПЕКТИВНИХ БЕЗПІЛОТНИХ АВІАЦІЙНИХ КОМПЛЕКСІВ
}

В статті показана необхідність створення для кожного операційного району угруповань безпілотних авіаџійних комплексів (БпАК). Відповідно до визначеного переліку завдань для БпАК проводиться визначення оптимального складу угруповань. В якості критерію оптимальності кількісноякісного складу (КЯС) угруповання перспективних БпАК пропонується критерій максимального наближення реалізованих показників ефективності (результативності) та живучості (стійкості) угруповання до встановлених нормативних або максимально-можливих значень ијих показників. В якості обмежень та умов щцодо застосування угруповання БпАК в задачі оптимізації розглядається: вартісні обмеження на створення угруповання та умови щзодо способів бойового застосування БпАК згідно прийнятої концепиії їх застосування. У задачі розглядаються альтернативні зразки БпАК, відносно яких, в результаті розв'язання задачі, визначаються компоненти вектора кількісно-якісного складу угруповання при визначеному варіанті концепції його застосування. Для кожного варіанту концепції буде мати місие свій вигляд залежностей ефективності, вартості застосування, живучості угруповання БпАК від КЯС.

Ключові слова: угруповання безпілотних авіачійних комплексів; кількісно-якісний склад; оптимізація.

\section{Вступ}

Можливості безпілотних авіаційних комплексів (БпАК) постійно зростають, сфера їхнього використання розширюється, бойова живучість підвищується. Більша кількість 3 них має малі розміри, низьку оптичну і радіолокаційну контрастність, тому вони менш уразливі засобами протиповітряної оборони (ППО) противника. В збройних силах зарубіжних країн вони все більш замінюють пілотуємі літальні апарати при виконанні бойових завдань із ведення розвідки, спостереження за полем бою, знищення наземних цілей, створення хибних повітряних цілей тощо.

Постановка проблеми. За останній період під час проведення антитерористичної операції на Сході України знайшли широке застосування як БпАК, що вже давно стоять на озброєнні Повітряних Сил (ПС) Збройних Сил (3С) України, так і ті, що були отримані по лінії волонтерської допомоги. При постійному збільшенні кількості БпАК постає задача визначення оптимального складу ї угруповання, а також просторового та функціонального їх розподілу між операційними районами.

Аналіз останніх досліджень і публікацій. 3 метою забезпечення оснащення ЗС України БпАК протягом останніх років проведено та виконується ряд досліджень щодо обгрунтування можливості створення вітчизняних безпілотних літальних апаратів (БпЛА) різного типу і призначення, які відповідають вимогам Міністерства Оборони України. Крім того, триває вивчення доцільності прийняття на озброєння ЗС України БпАК іноземного виробництва та вивчається можливість модернізації наявних БпАК з метою продовження термінів їх експлуатації, підвищення ефективності застосування у виконанні ними різних типів бойових завдань, які покладаються на ЗС.

Але будь-які питання оснащення повинні починатися вивченням кількісної потреби 3 урахуванням вартісних можливостей. Потреба у БпАК має визначатись, виходячи 3 можливостей тактичної авіації щодо виконання у повному обсязі визначених завдань, стану та можливості використання для цього наявного парку літаків. Крім цього, вона має визначатись з урахуванням потреби у можливому одночасному веденні бойових дій ЗС України у визначеній кількості операційних районів $[1-5,10,11]$.

Тому пропонується створення для кожного операційного району угруповань БпАК, до складу яких входять ударні, розвідувальні, БПЛА радіоелектронної боротьби (РЕБ), транспортні та БПЛА - активні пастки.

Для забезпечення бойової підготовки особового складу ПС ЗС України необхідно мати 
БпЛА - повітряні мішені, які дозволятимуть відпрацьовувати вправи зі знищення повітряних цілей. Щорічна потреба у таких БпЛА визначається 3 урахуванням кількості обслуг, екіпажів, які виконуватимуть бойові стрільби по повітряним мішеням.

Контроль параметрів радіолокаційних засобів зенітних ракетних комплексів можна проводити розвідувальними та БпЛА РЕБ $[14,15]$.

Окремим класом ударних БпЛА, якими можуть оснащатись ПС ЗС України, є ударні БпЛА одноразового використання, які матимуть високу швидкість та виконуватимуть задачі ураження наземних (морських) об'єктів противника [16-19].

Метою статті $\mathbf{\epsilon}$ розроблення методики обгрунтування раціонального складу перспективних БпАК ПС ЗС України та надання рекомендацій щодо раціонального складу перспективних БпАК ПС ЗС України за класами та типами.

\section{Виклад основного матеріалу дослідження}

Центральним складовим елементом методики обгрунтування раціонального складу перспективних безпілотних авіаційних комплексів Повітряних Сил ЗС України $є$ задача математичного програмування, в результаті розв'язання якої отримується оптимальний кількісно-якісний склад (КЯС) угруповання перспективних БпАК. Поняття оптимальності КЯС парку БПАК тут вводиться як його відповідність введеному критерію оптимальності та встановленим обмеженням i умовам щодо застосування угруповання перспективних БпАК.

В якості критерію оптимальності КЯС угруповання перспективних БпАК пропонується критерій максимального наближення реалізованих показників ефективності (результативності) та живучості (стійкості) угруповання до встановлених нормативних або максимальноможливих значень цих показників. В якості обмежень та умов щодо застосування угруповання БПАК в задачі розглядається: вартісні обмеження на створення угруповання та умови щодо способів бойового застосування БпАК згідно прийнятої концепції їх застосування [13].

Перелік показників ефективності, що входять до критерію оптимальності, залежить від видів завдань, що планується покласти на угруповання перспективних БпАК. Згідно результатів аналізу сучасних тенденцій розвитку та перспектив застосування угруповань БпАК на них планується покласти наступні завдання:

ураження засобів ядерного нападу (ЗЯН);

ураження сил та засобів ППО;

ураження балістичних головок у повітрі;

ураження живої сили та техніки на полі бою;

ураження повітряних та морських десантів;

ураження об'єктів наземної та морської інфраструктури; ведення повітряного бою 3 пілотованими та безпілотними авіаційними комплексами;

ведення всіх видів повітряної розвідки: радіологічної, бактеріологічної, хімічної та метеорологічної розвідки;

радіолокаційне виявлення та оповіщення;

цілевказівка та ретрансляція зв'язку в інтересах підрозділів Сухопутних Військ (СВ), ПС та Військово-Морських Сил (ВМС) 3С України; ведення РЕБ; створення хибних цілей;

повітряне перевезення (евакуація) особового складу, матеріальних засобів, боєприпасів та озброєння.

У мирний час БпАК застосовуються для забезпечення заходів бойової підготовки (імітація повітряних цілей, моніторинг районів бойових стрільб і результатів їхнього виконання та інше).

Результати аналізу завдань, що покладаються на цивільні та військові БпАК, показують, що вони мають як схожість так і ряд відмінностей, які впливають на організацію їхнього використання. Це дозволяє зробити висновок про те, що при визначенні вартості оснащення ПС безпілотними авіаційними комплексами треба враховувати можливість зниження вартості їхнього створення i експлуатації в ПС України за рахунок виконання ними завдань в інтересах інших державних відомств і навіть комерційних структур. Польоти на їх замовлення можна буде об'єднати 3 виконанням планів бойової підготовки безпілотної авіації.

3 наведеного переліку завдань ефективність (результативність) застосування угруповання БпАК слідує вимірювати за допомогою наступних груп (векторів) показників:

вектор показників щодо вимірювання обсягу збитку, який завдається противнику, $\mathrm{W}^{\mathrm{BУ}}$;

вектор показників щодо вимірювання ефективності повітряних перевезень своїх сил та

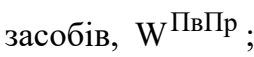

вектор показників щодо вимірювання ефективності всіх видів повітряної розвідки,

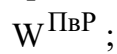

вектор показників щодо вимірювання ефективності РЕБ, $\mathrm{W}^{\text {РЕБ }}$;

вектор показників щодо вимірювання ефективності цілевказівки та забезпечення зв'язку в інтересах підрозділів $\mathrm{CB}$, ПС та ВМС 3С України, $\mathrm{W}^{Ц В к}$.

Сукупність векторів 3 оцінки ефективності застосування угруповання БпАК за видами завдань складають єдиний вектор ефективності, $\mathrm{E}=\left\{\mathrm{W}^{\mathrm{BУ}} ; \mathrm{W}^{\text {ПвПр }} ; \mathrm{W}^{\text {ПвР }} ; \mathrm{W}^{\text {РЕБ}} ; \mathrm{W}^{Ц В к}\right\}$.

Властивості стійкості (живучості) угруповання БпАК вимірюються вектором показників стосовно стійкості (тривалості існування) угруповання при виконанні наведених вище груп завдань, $\mathrm{G}=\left\{\mathrm{g}^{\mathrm{BУ}} ; \mathrm{g}^{\text {ПвПр }} ; \mathrm{g}^{\text {ПвР }} ; \mathrm{g}^{\text {РЕБ }} ; \mathrm{g}^{\text {ЦВк }}\right\}$.

Наведені групи показників залежать від 
кількісного складу та рівня технічної досконалості БпАК угруповання. Характер цих залежностей змінюється для різних варіантів концепції та умов застосування БпАК. Тобто

$$
\begin{aligned}
& \mathrm{E}=\mathrm{F}^{(\mathrm{E})}(\mathrm{N}, \mathrm{U}) \\
& \overline{\mathrm{p}}_{2, \text { СтОб }}^{\text {ППО }}=\mathrm{e}^{\left[-\lambda_{2, \text { СтОб }}^{\text {ЗРК СД }} \mathrm{t}_{2, \text { СтОб }}^{\text {ЗРК СД }}-\lambda_{2, \text { СтОб }}^{\text {ЗРК ВД }} \mathrm{t}_{2, \text { СтОб. }}^{\text {ЗРК ВД }}\right]}
\end{aligned}
$$

де $\mathrm{F}^{(\mathrm{E})}-$ функція, що встановлюють відповідність між значеннями показників ефективності застосування та стійкості (живучості) угруповання БпАК та характеристиками технічної досконалості комплексів, що використовуються, їх кількістю та характеристиками способів та умов застосування БпАК згідно визначеної концепції;

$$
\mathrm{N}=\left\{\mathrm{n}_{\mathrm{j}, \mathrm{h}}\right\} \text { - матриця кількісно-якісного }
$$
складу парку БпАК. Тут $\mathrm{n}_{\mathrm{j}, \mathrm{h}}$ позначає кількість БпАК ј-го виду 3 h-им рівнем технічної досконалості;

$\mathrm{U}$ - вектор показників щодо способу та умов застосування БпАК згідно визначеного варіанту концепції.

Функції $\mathrm{F}^{(\mathrm{E})}, \mathrm{F}^{(\mathrm{G})} \epsilon$ векторами, компонентами яких також $\epsilon$ функції відповідних показників ефективності або живучості від визначеного вище набору характеристик. Наприклад,

$$
F^{(G)}=\left(\begin{array}{c}
f^{g^{B У}} \\
\ldots \\
f^{g} \\
\ldots \\
f^{g^{\text {पВР }}}
\end{array}\right)
$$

де $\mathrm{f}^{\mathrm{g}^{\mathrm{BУ}}}, \ldots, \mathrm{f}^{\mathrm{g}^{\text {ПвР }}}, \ldots, \mathrm{f}^{\mathrm{g}^{\text {ЦВк }}}-$ функції, що встановлюють відповідність між значеннями показників стійкості угруповання БпАК під час виконання різних груп завдань (вогневе ураження, повітряна розвідка і так далі) та кількісно-якісним складом та характеристиками способів та умов застосування БпАК згідно визначеної концепції.

У задачі розглядаються альтернативні вже створені, або створювані, або гіпотетичні зразки БпАК, відносно яких, в результаті розв'язання задачі, визначаються компоненти вектора кількісно-якісного складу угруповання при визначеному варіанті концепції його застосування: $\mathrm{N}=\left\{\mathrm{n}_{\mathrm{j}, \mathrm{h}}\right\}$.

Для визначеного k-го варіанта концепції застосування, $\mathrm{U}=\mathrm{U}_{\mathrm{k}}$, відшукується такий КЯС, $\mathrm{N}_{\mathrm{k}}=\left\{\mathrm{n}_{\mathrm{j}, \mathrm{h}}\right\}_{\mathrm{k}}$, при якому досягається максимальне наближення до нормативних або максимально-можливих значень показників ефективності та стійкості угруповання БпАК [6-9]:

$$
\begin{aligned}
& \sum_{\mathrm{z}=1}^{\mathrm{N}^{\mathrm{By}}} \frac{\left(\mathrm{w}_{\mathrm{z}}^{\mathrm{By}}\right)^{*}-\mathrm{w}_{\mathrm{z}, \mathrm{k}}^{\mathrm{By}}\left(\left\{\mathrm{n}_{\mathrm{j}, \mathrm{h}}\right\}\right)}{\left(\mathrm{w}_{\mathrm{z}}^{\mathrm{By}}\right)^{*}}+\ldots+
\end{aligned}
$$

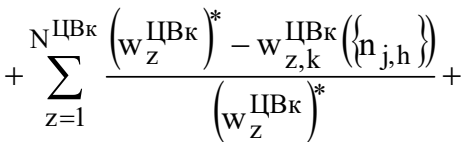

$$
\begin{aligned}
& +\frac{\left(g^{B Y}\right)^{*}-g_{k}^{B y}\left(\left\{n_{j, h}\right\}\right)}{\left(g^{B Y}\right)^{*}}+\ldots+
\end{aligned}
$$

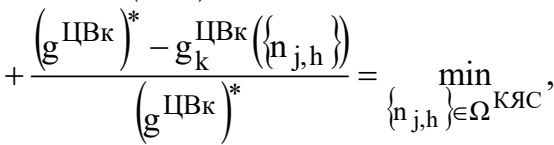

де $\mathrm{N}^{\mathrm{BУ}}, \ldots, \mathrm{N}^{\text {ЦВк }}$ - кількість завдань за їх видами (завдання вогневого ураження, повітряні перевезення, завдання повітряної розвідки і так далі);

$$
\mathrm{w}_{\mathrm{z}, \mathrm{k}}^{\mathrm{BУ}}\left(\left\{\mathrm{n}_{\mathrm{j}, \mathrm{h}}\right\}\right), \ldots, \mathrm{w}_{\mathrm{z}, \mathrm{k}}^{\mathrm{ЦВ \kappa}}\left(\left\{\mathrm{n}_{\mathrm{j}, \mathrm{h}}\right\}\right) \text { - часткові }
$$

показники ефективності виконання визначених переліків завдань перспективним угрупованням БпАК, яке має КЯС $\left\{\mathrm{n}_{\mathrm{j}, \mathrm{h}}\right\}$, при реалізації k-ої концепції застосування БпАК;

$$
\left(\mathrm{w}_{\mathrm{Z}}^{\mathrm{BУ}}\right)^{*}, \ldots,\left(\mathrm{w}_{\mathrm{Z}}^{\mathrm{LB \kappa}}\right)^{*}-\text { максимально-досяжні }
$$
значення часткових показників ефективності;

$\mathrm{g}_{\mathrm{k}}^{\mathrm{BУ}}\left(\left\{\mathrm{n}_{\mathrm{j}, \mathrm{h}}\right\}\right), \ldots, \mathrm{g}_{\mathrm{k}}^{Ц \mathrm{LК}}\left(\left\{\mathrm{n}_{\mathrm{j}, \mathrm{h}}\right\}\right)$ - показники стійкості угруповання БпАК, що має КЯС $\left\{\mathrm{n}_{\mathrm{j}, \mathrm{h}}\right\}$, під час виконання визначеного переліку завдань при реалізації k-ої концепції застосування БПАК;

$$
\left(\mathrm{g}^{\mathrm{BУ}}\right)^{*}, \ldots,\left(\mathrm{g}^{Ц \mathrm{BK}}\right)^{*} \text { - максимально-досяжні }
$$
показники стійкості угруповання БпАК за видами завдань;

$$
\left\{\mathrm{n}_{\mathrm{j}, \mathrm{h}}\right\}-\mathrm{KЯC} \text { парку БпАК, якими }
$$
укомплектоване перспективне безпілотне авіаційне угруповання;

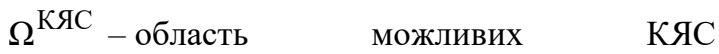

перспективного угруповання БпАК, яке може бути реалізованим за ресурснимобмеженнями та умовами щодо мінімально-припустимих рівнів ефективності i живучості застосування угруповання безпілотної авіації.

В якості ресурсних обмежень, на підставі яких формується область можливих КЯС угруповання БпАК, виступають обмеження на загальну середньорічну вартість утримання та очікувану вартість бойового застосування, згідно прийнятої концепції застосування, частин (підрозділів) безпілотної авіації. У загальному вигляді ці обмеження можуть бути подані як [12]:

$$
\sum_{\mathrm{j}=1}^{\mathrm{N}^{\text {в.БпАК }}} \sum_{\mathrm{h}=1}^{\mathrm{H}}\left(\mathrm{c}_{\mathrm{j}, \mathrm{h}}^{\text {експ. }}+\varphi_{\mathrm{j}, \mathrm{h}} \mathrm{c}_{\mathrm{j}, \mathrm{h}}^{\mathrm{iн \phi}}\right) \mathrm{n}_{\mathrm{j}, \mathrm{h}} \leq \mathrm{C}_{\text {макс. }}^{\text {експ. }},
$$




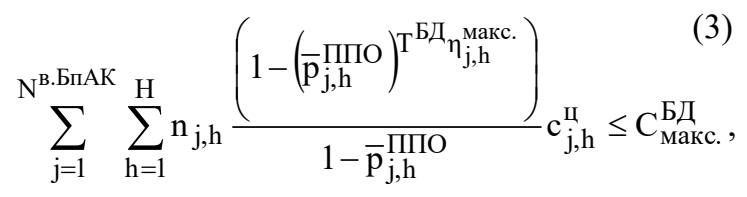

де $\mathrm{N}^{\text {в.БпАК }}$ - кількість видів БпАК, які враховуються при розв'язанні задачі оптимізації КЯС парку БпАК;

Н - кількість ступенів технічної досконалості БПАК;

$\mathrm{c}_{\mathrm{j}, \mathrm{h}}^{\text {експ. }}$ - експлуатаційні середньорічні витрати на утримання одного БпАК ј-го виду һ-го рівня технічної досконалості;

$\mathrm{c}_{\mathrm{j}, \mathrm{h}}^{\mathrm{iн \phi}}$ - середньорічні експлуатаційні витрати на інфраструктуру для забезпечення використання БпАК ј-го виду h-го рівня технічної досконалості;

$\varphi_{\mathrm{j}, \mathrm{h}}-$ коефіцієнт, який вказує, яка частка експлуатаційних витрат на інфраструктуру припадає на один БпАК відповідного виду та відповідного рівня технічної досконалості;

$\overline{\mathrm{p}}_{\mathrm{j}, \mathrm{h}}^{\text {ППО }}$ - ймовірність успішного подолання ППО противника БПАК ј-го виду h-го рівня технічної досконалості;

$\eta_{\mathrm{j}, \mathrm{h}}^{\text {макс. }}$ - максимально-припустима напруженість бойових дій (кількість вильотів за добу) для БпАК ј-го виду һ-го рівня технічної досконалості;

$\mathrm{T}^{\text {БД }}$ - встановлена тривалість бойових дій;

$\mathrm{c}_{\mathrm{j}, \mathrm{h}}^{\amalg}$ - вартість одного циклу застосування

БпАК ј-го виду h-го рівня технічної досконалості;

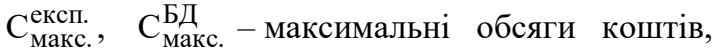
що можуть бути витраченими на здійснення експлуатації та бойове застосування, протягом визначеного періоду бойових дій, угруповання БпАК.

Обмеження щодо мінімально-припустимих рівнів ефективності і живучості застосування угруповання безпілотної авіації мають наступний вигляд:

$$
\begin{aligned}
& \mathrm{E}\left(\left\{\mathrm{n}_{\mathrm{j}, \mathrm{h}}\right\}\right) \geq \mathrm{E}^{\text {мін.прип. }}, \\
& \mathrm{G}\left(\left\{\mathrm{n}_{\mathrm{j}, \mathrm{h}}\right\}\right) \geq \mathrm{G}^{\text {мін.прип. }},
\end{aligned}
$$

де $\mathrm{E}^{\text {мін.прип. }}, \mathrm{G}^{\text {мін.прип. - вектори мінімально- }}$ припустимих значень показників ефективності виконання завдань та живучості угруповання БПАК;

$\mathrm{E}\left(\left\{\mathrm{n}_{\mathrm{j}, \mathrm{h}}\right\}\right), \quad \mathrm{G}\left(\left\{\mathrm{n}_{\mathrm{j}, \mathrm{h}}\right\}\right) \quad$ - вектори прогнозованих значень показників ефективності та живучості для заданого КЯС угруповання БпАК.

Отже з урахуванням наведеного вище загальна постановка задачі оптимізації складу перспективних БпАК ПС ЗС України для визначеного варіанту концепції застосування буде мати наступний вигляд:

$$
\begin{aligned}
& \sum_{i=1}^{N^{B y}} \frac{\left(w_{i}^{B y}\right)^{*}-w_{i, k}^{B y}\left(\left\{n_{j, h}\right\}\right)}{\left(w_{i}^{B y}\right)^{*}}+\ldots \\
& +\sum_{j=1}^{N^{Ц В к}} \frac{\left(w_{j}^{Ц B \kappa}\right)^{*}-w_{j, k}^{Ц B \kappa}\left(\left\{n_{j, h}\right\}\right)}{\left(w_{j}^{\lfloor B \kappa}\right)^{*}}+\ldots \\
& +\frac{\left(g^{B y}\right)^{*}-g_{k}^{B y}\left(\left\{n_{j, h}\right\}\right)}{\left(g^{B Y}\right)^{*}}+\ldots \\
& +\frac{\left(g^{Ц В \kappa}\right)^{*}-g_{k}^{Ц В \kappa}\left(\left\{n_{j, h}\right\}\right)}{\left(g^{Ц В \kappa}\right)^{*}}=\min _{\left\{n_{j, h}\right\} \in \Omega^{К Я Я ~}}, \\
& \sum_{\mathrm{j}=1}^{\mathrm{N}^{\text {в.БпАК }}} \sum_{\mathrm{h}=1}^{\mathrm{H}}\left(\mathrm{c}_{\mathrm{j}, \mathrm{h}}^{\text {експ. }}+\varphi_{\mathrm{j}, \mathrm{h}} \mathrm{c}_{\mathrm{j}, \mathrm{h}}^{\mathrm{iн} .}\right) \mathrm{h}_{\mathrm{j}, \mathrm{h}} \leq \mathrm{C}_{\text {макс. }}^{\text {експ. }}
\end{aligned}
$$

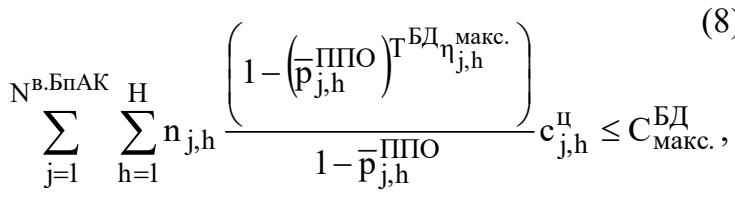

$$
\begin{aligned}
& \mathrm{E}\left(\left\{\mathrm{n}_{\mathrm{j}, \mathrm{h}}\right\}\right) \geq \mathrm{E}^{\text {мін.прип. }} \\
& \mathrm{G}\left(\left\{\mathrm{n}_{\mathrm{j}, \mathrm{h}}\right\}\right) \geq \mathrm{G}^{\text {мін.прип. }}
\end{aligned}
$$

Остаточно, раціональний КЯС угруповання БпАК визначається як:

$$
\forall \mathrm{j}=\overline{1 ; \mathrm{N}^{\text {в.БпАК }}}, \mathrm{i}=\overline{1 ; \mathrm{H}}: \mathrm{n}_{\mathrm{j}, \mathrm{i}}^{\text {paц. }}=\max _{\mathrm{k}} \mathrm{n}_{\mathrm{j}, \mathrm{h}, \mathrm{k}}^{\mathrm{onT}},
$$

де $\mathrm{n}_{\mathrm{j}, \mathrm{h}, \mathrm{k}}^{\mathrm{onT}}$ - оптимальна чисельність БпАК j-го виду і-го рівню технічної досконалості, яка визначена при розв'язанні задачі оптимізації (6)(10) для k-го варіанту концепції застосування угруповання БпАК;

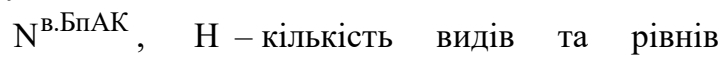
технічної досконалості БпАК, що розглядається;

$\mathrm{n}_{\mathrm{j}, \mathrm{i}}^{\text {рац. }}$ - раціональна чисельність БпАК ј-го виду і-го рівню технічної досконалості.

\section{Висновки й перспективи подальших досліджень}

Раціональний КЯС угруповання БпАК визначається на підставі розв'язання кількох задач оптимізації (6)-(10) для різних варіантів концепції застосування безпілотної авіації.

Для кожного варіанту концепції буде мати місце свій вигляд залежностей ефективності, вартості застосування, живучості угруповання БПАК від КЯС $\left\{\mathrm{n}_{\mathrm{j}, \mathrm{h}}\right\}$.

Кожен варіант концепції застосування висуває ISSN2311-7249(Print)/ISSN2410-7336(Onfine) Сучасні інббормаційні технологіï у сббері безпеки та оборони № 3 (33)/2018 
свої особливі умови та ресурсні обмеження стосовно мінімально-припустимих рівнів ефективності та живучості угруповання БпАК.

\title{
Лimepamypa
}

1. Воєнне мистецтво в локальних війнах 90 -х років $\mathrm{XX}$ початку XXI століть: Навчальний посібник / [M.I. Рибак, Р.М. Факадей, С. П. Мосов та ін.]; під ред. В.Б. Толубко. - К.: НАОУ, 2004. - 176 с. 2. Толубко В.Б. Основні закономірності сучасних локальних війн та збройних конфліктів: Навчальний посібник / В.Б. Толубко, Ю.І. Бут, В.О. Косевцов. - К.: НАОУ, 2002. - 68 с. 3. Прогнозування втрат військ і об'єктів від авіаційних ударів противника / [Онищенко C.I., Загорка О.М., Коваль В.В., Тюрін В.В.]. // Системи озброєння і військова техніка. - 2011. - № 2 (26). - С. 2-8. 4. Оніщенко С.I. До питання розподілення сил та визначення послідовності завдання ракетно-авіаційних ударів у повітряній операції / Оніщенко C.I., Загорка О.М., Коваль В.В. // Наука і оборона. - 2012. № 1. - С. 39-44. 5. Системний аналіз бойового застосування комплексів авіаційного озброєння: Навч. посіб. для слух., курс. та студ. ВНЗ / Б.Б. Головко, С.А. Калкаманов, М.М. Момот, В.М. Хижняк. - 2-ге вид., виправл. і доп. - Х.: МОУ, 2012. - 212 с. 6. Лазебник С.В. Підхід до формування показників ефективності угруповань військ / С.В. Лазебник, В.Г. Малюга, В.О. Нерубацький // Зб. наук. праць ХУПС. - Харків: 2012. - № 4. - С. 43-46. 7. Елементи дослідження складених систем військового призначення / [О.М. Загорка, С.П. Мосов, А.І. Сбітнєв та ін.]. - К.: HAOY, 2005. - 100 c. 8. Harrington E.C. The Desirability Function. / Industrial Quality Control. - 1965, vol. 21, № 10. - Р. 494-498. 9. Плюта В. Сравнительный многомерный анализ в экономических исследованиях: Методы таксономии и факторного анализа / Перевод с польск. В.В. Иванова. - М.: Статистика, 1980. - 151 с.
10. Методологічні засади обгрунтування складу угруповання військ (сил) для відбиття агресії: воєннотеоретична праця / [В.М. Телелим, О.М. Загорка, В.В. Стрижевський та ін.]. - К.: НУОУ ім. Івана Черняховського, 2013. - 368 с. 11. Методологічні засади обгрунтування раціональних форм та способів застосування угруповань військ (сил): Воєннотеоретична праця / [В.Г. Радецький, I.C. Руснак, О.М. Загорка та ін.]; за заг. ред. С. О. Кириченка - К.: НАОУ, 2007. - 288 с. 12. Юрков Б.Н. Исследование операций. - М.: ВИА им. Куйбышева, 1990. - 528 с. 13. Щипанський П.В. Визначення основних тактикотехнічних вимог та показників ефективності стратегічного розвідувального безпілотного авіаційного комплексу / П.В. Щипанський, М.В. Кас'яненко, O.P. Мартинюк // Наука i техніка Повітряних Сил Збройних Сил України. - Харків: ХУПС, 2014. - № 1 (14). - с. 56-59. 14. Опенько П.В. Обгрунтування підходів щодо використання безпілотних літальних апаратів для контролю параметрів радіолокаційних засобів ЗРК / П.В. Опенько, П.А. Дранник, В.В. Кобзєв, Г.М. Зубрицький // Сучасні інформаційні технології у сфері безпеки та оборони. - Вип. № 1(25) - К.: НУОУ, 2016. - С. 82-86. 15. Опенько П.В. Застосування безпілотних літальних апаратів для контролю параметрів радіолокаційних засобів зенітних ракетних комплексів / П.В. Опенько, В.В. Ткачов, В.В. Кобзєв, В.А. Васильєв // Наука і оборона. - Вип. № 3/4 - 2017. C. 61-65. 16. AJP-3.5 / Allied Joint Doctrine For Special Operations (RD), dtd. January 2009. 17. ADRP 3-05. 18. FM 34-36. 19. SOTG Manual - Final Draft 04/30/2009.

\section{МЕТОДИКА ОБОСНОВАНИЯ РАЦИОНАЛЬНОГО СОСТАВА ПЕРСПЕКТИВНЫХ БЕСПИЛОТНЫХ АВИАЦИОННЫХ КОМПЛЕКСОВ}

Павел Викторович Опенько (канд. техн. наук)

Алексей Ростиславович Мартинюк (канд. техн. наук) ${ }^{1}$

Игорь Николаевич Клюшников (канд. техн. наук, старший научный сотрудник) ${ }^{2}$

Алексей Виленинович Никифоров (канд. техн. наук, стариий научный сотрудник)

\begin{abstract}
${ }^{1}$ Национальный университет обороны Украины имени Ивана Черняховського, Киев, Украина ${ }^{2}$ Харьковской национальный университет Воздуиных Сил имени Ивана Кожсеуба, Харьков, Украина
\end{abstract}

В статье показанная необходимость создания для каждого операционного района группировок беспилотных авиационных комплексов (БпАК). В соответствии с определенным перечнем заданий для БиАК проводится определение оптимального состава группировок. $B$ качестве критерия оптимальности количественно-качественного состава (ККС) группировки перспективных БпАК предлагается критерий максимального приближения реализованных показателей эффективности (результативности) и живучести (стойкости) группировки к установленным нормативным или максимально-возможным значениям этих показателей. В качестве ограничений и условий относительно применения группировки БпАК в задаче оптимизачии рассматриваются стоимостнье ограничения на создание группировки и условия относительно способов боевого применения БпАК согласно принятой концепиии их применения. В задаче рассматриваются альтернативные образиьы БпАК, относительно которых, в результате решения задачи, определяются компоненты вектора количественнокачественного состава группировки при определенном варианте кониепции ее применения. Для каждого варианта концепциии будет иметь место свой вид зависимостей эффективности, стоимости применения, живучести группировки БпАК от ККС.

Ключевые слова: группировка беспилотных авиаџионных комплексов; количественнокачественный состав; оптимизация.

\section{TECHNIQUE OF JUSTIFICATION OF THE RATIONAL STRUCTURE OF PERSPECTIVE} UNMANNED AERIAL SYSTEMS 


\author{
Pavlo V. Openko (Candidate of Technical Sciences) ${ }^{1}$ \\ Oleksii R. Martyniuk (Candidate of Technical Sciences) ${ }^{1}$ \\ Ihor M. Kliushnikov (Candidate of Technical Sciences, Senior Researcher) ${ }^{2}$ \\ Oleksii V. Nykyforov (Candidate of Technical Sciences, Senior Researcher) ${ }^{2}$
}

\title{
${ }^{1}$ National Defence University of Ukraine named after Ivan Cherniakhovskyi, Kyiv, Ukraine ${ }^{2}$ Kharkiv National University of Air Force named after Ivan Kozhedub, Kharkiv, Ukraine
}

The article shows the need to create unmanned aerial systems (UAS) group for each operational area. In accordance with a certain list of tasks for UAS, the determination of the optimal composition of groups is carried out. As an optimality criterion for the quantitative and qualitative composition (QQC) of the group of prospective UAS, a criterion is proposed for the maximum approximation of the implemented performance (effectiveness) indicators and survivability (persistence) of the group to the established normative or maximum possible values of these indicators. As constraints and terms of use of the UAS group, the optimization problem considers cost restrictions on the creation of a group and conditions regarding the methods of combat use of the $U A S$ according to the accepted concept of their use. The task considers alternative UAS samples, for which, as a result of solving the problem, the components of the vector of QQC of the group are determined with a certain variant of its application concept. For each version of the concept, there will be a different type of dependency of efficiency, cost of use, survivability of the UAS group from the QQC.

Keywords: unmanned aerial systems group; quantitative and qualitative composition; optimization.

\section{References}

1. Rybak, M.I., Fakadey, R.M., Mosov, S.P. and others (2004), Military art in the local wars of the 90s of the XXth - beginning of the XXI centuries: Textbook [Voyenne mystetstvo $v$ lokal'nykh viynakh 90-kh rokiv XX-pochatku XXI stolit': Navchal'nyy posibnyk], (ed. Tolubko, V.B.), NAOU, Kyiv, 176 p. 2. Tolubko, V.B., Booth, Yu.I. and Kosevtsov, V.O. (2002), Basic regularities of modern local wars and armed conflicts: Textbook, [Osnovni zakonomirnosti suchasnykh lokal'nykh viyn ta zbroynykh konfliktiv: Navchal'nyy posibnyk], NAOU, Kyiv, 68 p. 3. Onischenko, S.I., Zagorka, O.M., Koval, V.V. and Tyurin, V.V. (2011), Forecasting of losses of troops and objects from enemy air strikes / [Prohnozuvannya vtrat viys'k $i$ ob"yektiv vid aviatsiynykh udariv protyvnyka], Systemy ozbroyennya i viys'kova tekhnika, No. 2 (26), pp. 2-8. 4. Onischenko, S.I., Zagorka, O.M. and Koval, V.V. (2012), On the issue of the distribution of forces and the determination of the sequence of missile and air strikes in an air operation [Do pytannya rozpodilennya syl ta vyznachennya poslidovnosti zavdannya raketno-aviatsiynykh udariv u povitryaniy operatsiyi], Nauka i oborona, No. 1, Kyiv, pp. 39-44. 5. Golovko, B.B., Kalkamanov, S.A., Momot, M.M. and Khizhnyak, V.M. (2012), System analysis of military applications of aircraft weapons: Manual for High school [Systemnyy analiz boyovoho zastosuvannya kompleksiv aviatsiynoho ozbroyennya: Navch. posib. dlya slukh., kurs. ta stud. VNZ], (2nd issue), MOU, Kharkiv, 212 p. 6. Lazebnik, S.V., Maluga, V.G. and Nerubatsky, V.O. (2012), Approach to the formation of indicators of the effectiveness of troop groups [Pidkhid do formuvannya pokaznykiv efektyvnosti uhrupovan' viys'k], Zbirnyk naukovykh prats', No. 4, KHUPS, Kharkiv, pp. 43-46. 7. Zagorka, O.M., Mosov, S.P., Sbitnev, A.I. and others. (2005), Elements of research of the complex military systems [Elementy doslidzhennya skladenykh system viys'kovoho pryznachennya], NAOU, Kyiv, 100 p. 8. Harrington, E.C. (1965) The Desirability Function. Industrial Quality Control, vol. 21, no. 10, pp. 494-498. 9. Plyuta V. (1980), Comparative multidimensional analysis in economic studies: Methods of taxonomy and factor analysis [Sravnitel'nyy mnogomernyy analiz $v$ ekongmicheskikh issledovaniyakh: Metody taksonomii $i$ faktornogo analiza], (Transl. from Polish, Ivanova, V.V.), Statistics, Moscow, 151 p. 10. Telelim, V.M., Zagorka, O.M., Strizhevsky, V.V. and others (2013), Methodological foundations of the composition of the grouping of troops (forces) to reject aggression: military-theoretical work [Metodolohichni zasady obgruntuvannya skladu uhrupovannya viys'k (syl) dlya vidbyttya ahresiyi: voyennoteoretychna pratsya], NUOU, Kyiv, 368 p. 11. Radetsky, V.G., Rusnak, I.S., Zagorka, O.M. and others (2007), Methodological foundations for rational forms and methods justification of using groups of forces: Military-theoretical work [Metodolohichni zasady obgruntuvannya ratsional'nykh form ta sposobiv zastosuvannya uhrupovan' viys'k (syl): Voyenno-teor. pratsya] (Ed. Kirichenko, S.O.), NUOU, Kyiv, 288 p. 12. Yurkov B.N. (1990), Operations research [Issledovaniye operatsiy], VIA, Moscow, 528 p. 13. Shchypanskyi, P.V., Kasianenko, M.V. and Martyniuk, O.R. (2014), Definitions of the main operational requirements and performance measures for strategic ISR unmanned aircraft systems [Vyznachennya osnovnykh taktyko-tekhnichnykh vymoh ta pokaznykiv efektyvnosti stratehichnoho rozviduval'noho bezpilotnoho aviatsiynoho kompleksu], Nauka i tekhnika Povitryanykh Syl Zbroynykh Syl Ukrayiny, vol. 1 (14), KHUPS, Kharkiv, pp. 56-59. 14. Openko, P.V., Drannik, P.A., Kobzev, V.V. and Zubrytsky, G.M. (2016), Substantiation of approaches to the use of unmanned aerial vehicles for control of radar equipment parameters [Obgruntuvannya pidkhodiv shchodo vykorystannya bezpilotnykh lital'nykh aparativ dlya kontrolyu parametriv radiolokatsiynykh zasobiv ZRK], Suchasni informatsiyni tekhnolohiyi u sferi bezpeky ta oborony, Issue No. 1 (25), NUOU, Kyiv, pp. 82-86. 15. Openko P.V., Tkachev, V.V., Kobzev, V.V. and Vasiliev, V.A. (2017), Application of UAV for controlling parameters of radar equipment of anti-aircraft missile systems [Zastosuvannya bezpilotnykh lital'nykh aparativ dlya kontrolyu parametriv radiolokatsiynykh zasobiv zenitnykh raketnykh kompleksiv] Nauka i oborona, Issue No. 3/4, pp. 61-65. 16. AJP-3.5, Allied Joint Doctrine For Special Operations (RD), dtd. January 2009. 17. ADRP 305. 18. FM 34-36. 19. SOTG Manual - Final Draft $04 / 30 / 200$ 